\title{
A. H. ANDERSON, 1901-1967
}

\author{
David M. Pendergast
}

$\mathrm{O}^{\mathrm{N}}$ N MAY 24, 1967, shortly after his retirement as Archaeological Commissioner of British Honduras, A. H. Anderson died in England of a coronary thrombosis following major surgery. His death not only further thins the meager ranks of Mayanists, but also brings to a close an era in the archaeology and the very way of life of British Honduras. The country does not seem the same without Hamilton, whose years stretched from colonial times to the threshold of independence, and from the expeditions of Gann and Joyce to those of Pennsylvania, Harvard, and the Royal Ontario Museum. The mark which he left on the archaeology of the country, and on all those who knew him, will remain for many years to come.

Hamilton was born on November 30, 1901, in Melbourne, Australia, to Scottish Presbyterian missionary parents. Though life led him through many lands, he was always a Scot and proud of it, and he often found that his heritage served him well in the tasks to which he dedicated himself. After a brief period in Australia, the Anderson family moved to a new post in Kenya, where much of Hamilton's early schooling was completed in Nairobi. From here, he was sent to Glasgow, where he served out an apprenticeship in metalworking, electricity, and hardware. This was the only lengthy time he ever spent in the country of his ancestors, and it seems to have served to strengthen the Scottish streak in him.

In his early twenties, Hamilton, by now striking out on his own, went out to Burma and became director of a department in the chain of Rowe \& Company stores, a post which took him over much of Burma and gave him a wide knowledge of Burmese language and customs. Hamilton's time in Burma was a happy one, and he might well have stayed on in the country, had it not been for an urgent appeal from his father, who was now in declining health, begging him as the only son to come out to assist the family in their new post in British Honduras. Hamilton went out to British Honduras in 1927 for a brief stay, or so he thought; after his father's death, his soiourn lengthened to 40 years, and British Honduras virtually became his home, though the ties with the British Isles were never severed.
Hamilton's decision to remain in British Honduras was dictated at first by the necessity of settling family affairs, and for a brief period he even filled his father's place, serviñg as minister of Scot's Kirk, an effort which was fondly recalled by older members of the congregation at the memorial service at the Kirk on June 6. By the time the press of family affairs no longer required his presence, Hamilton had apparently taken to British Honduras, and he decided to stay on, accepting a post as Private Secretary to the Governor of the colony, a position which he held until the early 1930's. During this time he met Miss Irma Hudson, daughter of a Colonial Service officer posted in British Honduras, and on November 30, 1929, they were married. Their daughter Sylvia, now Mrs. David Woods, resides in England. Following his term as Private Secretary, Hamilton worked for a time with Pan American Airways, but the depression doldrums prevented expansion of air service to the country, and he transferred to the Belize Estate and Produce Company, working in their mahogany operations.

In 1935, he returned to government service and, as Librarian, developed the Jubilee Library, the basis of the present library service in the country. Typically, Hamilton not only oversaw the acquisition of collections and layout of stacks, but he also designed the furniture and supervised its construction. From 1939 to 1942 he served as Assistant, then Chief Price Control Officer, and in 1942 he became a District Commissioner, serving first in Stann Creek and then in the Cayo District. In 1952 he was appointed to the post of First Assistant Secretary (General), with responsibility for archaeology, and in 1957 he became the first Archaeological Commissioner of British Honduras, which post he held until his retirement. He was also awarded the M.B.E. in 1957. In addition to being a member of the Society for American Archaeology and a Fellow of the Royal Anthropological Society. Hamilton served on numerous councils and other bodies in British Honduras, among them the National Parks Study Group, the National Archives Advisory Board, and the Bliss Institute Advisory Committee.

The variety which marked Hamilton's earlier years, plus his long stay in British Honduras, 


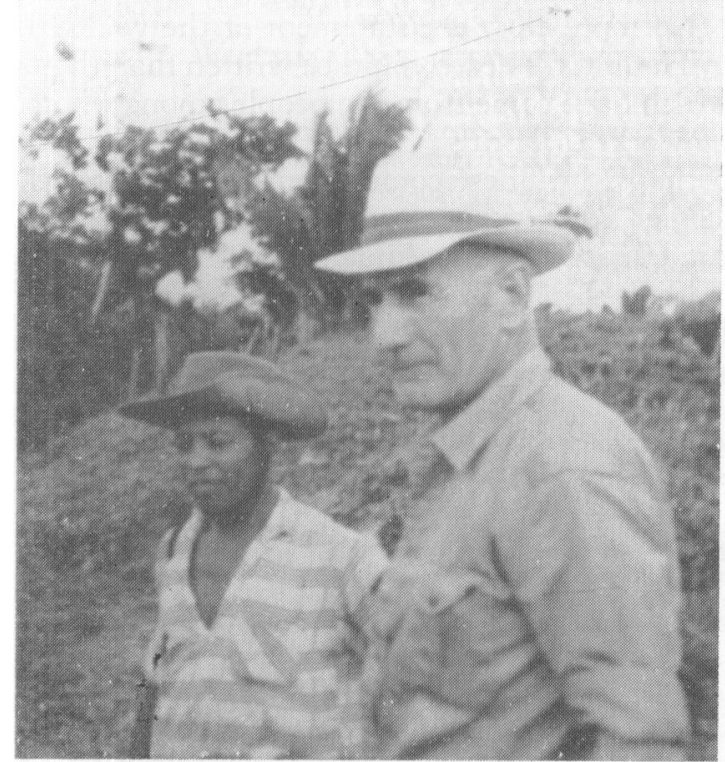

A. H. Anderson

made him seem the archetypal British civil servant, capable of mastering any task set before him, from archaeology, his first love, to designing and constructing roads and airstrips, dynamiting, wiring and laying out stage lighting, rebuilding vehicles and anything else with or without moving parts, serving as a magistrate, breaking up log jams - the list could go on for many pages. Above all else, though, Hamilton was a skilled and wonderful storyteller. With his excellent memory for people, places, and events, coupled with the gift of being able to re-create these so clearly that others could experience them through him, he filled many bush-camp nights with tales of canoe trips in Africa, the life of an oldtime blacksmith in Scotland, bicycle journeys through Burma, and the myriad of happenings during his years in British Honduras, to which he could add stories drawn from his extensive research in the country's archives, in pursuit of another main interest, the early history of the colony. Hamilton often expected much of the younger listener, and would casually insert in a story about, say, dynamiting a block of porphyry prior to some construction work, a comment such as, "of course you know how this is done." On being apprised of the listener's ignorance, he would proceed to describe the process in sufficient detail to allow one to carry out similar work with his story as a guide. Very often Hamilton's stories about British Honduras were packed with basic information on the country and on life in the bush in general, and I, like many others who have worked in the country, owe much of my knowledge of it to him.

Though many of Hamilton's stories dealt with his early archaeological work in the country, I never learned precisely what it was that led him to pursue this interest. I suspect, though, that his contacts with archaeologists during the time he served as Private Secretary to the Governor in the early 1930's were the initial sparks of what grew to be his lifework. It might be said, however, that his first archaeological endeavor grew out of another job, for, while with Pan American, Hamilton met Charles Lindbergh during the latter's flight through Latin America, and the two made a short flight over British Honduras in an attempt at aerial survey for sites. Whatever the beginnings, it is certain that by the mid-1930's Hamilton's archaeological interests were well awakened, for he incorporated into the Jubilee Library a series of wellplanned exhibits on the natural history and archaeology of British Honduras, and he became, in effect, curator of the colony's first museum.

In 1937 and 1938, Hamilton's archaeological activity broadened to include salvage excavation at Santana, in northern British Honduras, and exploration of Awe Cave (Las Cuevas) and Caracol, the latter two of which he named. Though he submitted manuscript reports on these operations to the Governor, Hamilton did not attempt publication. Later, when his service as District Commissioner brought him back after World War II to the Cayo District, Hamilton continued archaeological work as time permitted. In 1949 he rediscovered and partially cleared an extensive stucco frieze at Xunantunich (Benque Viejo), part of which was excavated subsequently by Linton Satterthwaite in 1950, as a result of Hamilton's initial efforts. Hamilton returned in the mid-1950's to complete work on the frieze, and in the years that followed he concentrated his efforts on Xunantunich, developing it as a tourist attraction while carrying out such excavations as were possible with limited funds and time.

In all of his archaeological work, and in the help he gave to others, Hamilton was famous for his ability to draw on his Scottish background and make one dollar do the work of many, not only where excavations were concerned but also 
in such undertakings as rebuilding the battered pile of junk which was all that remained of his Land Rover after Hurricane Hattie in 1961, and in keeping it running somehow until 1964, when he was given a new vehicle. As a small tribute to his abilities in this realm, the old Land Rover continues in service to this day.

Hamilton realized from the start that the economy of British Honduras could not support extensive archaeological work, and hence he directed his efforts to the task of attracting the interest of other countries and institutions to this part of the eastern periphery of the Maya area. To this end, he traveled to many meetings of the International Congress of Americanists, usually presenting a paper on his own work, but with the major purptise of speaking with archaeologists from abroad and acquainting them with the archaeological potential of British Honduras. Such efforts played a large part in the attraction of Pennsylvania and Harvard to the country in the early and middle 1950's, and they were directly responsible for the current presence of the Royal Ontario Museum. In every case, from the time prior to his assumption of the post of Archaeological Commissioner when he worked with Pennsylvania at Caracol, to more recent years, Hamilton gave unstintingly of his time, effort, and knowledge in the aid of those whose work was often, unfortunately, of such a scale as to dwarf his own contributions.

Many men build their monuments from publications, but Hamilton did not. The list of his published works is short, reflecting more than anything else the hundreds of nonarchaeological tasks which took his time awav from what he would have preferred to do. Too, for lack of money, laboratory space, and equipment, many of Hamilton's excavation proiects remain unrevorted. But true understanding of Hamilton's onntribution comes not from assessing his published work: it lies, rather, in the many acknowledoments to him in the reports of others, both nublished and vet to be written. Hamilton would not have thought of building a monument, I am sure, for he was always modest and unassuming when it came to his archaeolngical work. Yet he did build a lasting memorial in the form of the Denartment of Archaeologv and the wide interest in archaeology in British Honduras. neither of which would have come into being without his years of dedicated effort. He made a small beginning, to be sure, but it was a beginning, and those who follow after him in the country will be forever in his debt.

No more eloquent statement of the void left by Hamilton's death could be written than those which have come from the people among whom he worked in British Honduras. Of all of these, perhaps the finest comes from the Andersons' former cook, who closed her simple letter of condolence to Mrs. Anderson with the words, "Whole Belize miss him, from black to white." In this feeling, all of us who knew and worked with Hamilton sadly concur.

\section{BIBLIOGRAPHY}

1939 Brief Sketch of British Honduras. (Revised 1944 $1948,1952,1958,1963)$. Includes section on archaeology. Government Printing Service, Belize City.

1944 (with Herbert J. Cook) Archaeological Finds near Douglas, British Honduras. Carnegie Institution of Washington Notes on Middle American Archaeology and Ethnology, Vol. 2, No. 40, pp. 83-92. Washington.

1952 Archaeology in British Honduras Today. Proceedings of the Thirtieth International Congress of Americanists, Cambridge, 1952 , pp. 32-5. Royal Anthropological Institute, London.

Glimpses of a Lost Civilization. Caribbean Quarterly, Vol. 2, No. 2, pp. 24-9. Government Printing Office, Trinidad.

1958 Recent Discoveries at Caracol Site, British Honduras. Proceedings of the Thirty-Second International Congress of Americanists, Copenhagen, 1956, pp. 494-9. Copenhagen.

Anthropological Activities in British Honduras. Boletín Bibliográfico de Antropologia Americana, Vols. 19-20, No. 1, pp. 77-8. Mexico.

1959 More Discoveries at Caracol, British Honduras. Actas del XXXIII Congreso Internacional de Americanistas, San José, Costa Rica, 1958, Vol. 2, pp. 211-18. Lehmann, San José.

1960 Brief Guide to the Ancient Maya Ruins of Xunantunich, in the Cayo District, British Honduras. Government Printing Service, Belize City.

1962 Cave Sites in British Honduras. Akten des 34. Internationale Amerikanisten-Kongresses, Wien, 1960, pp. 326-31. Verlag Ferdinand Berger, Horn, Vienna.

1966 Ancient Maya Vaulted Masonry Drain and Related Works at Xunantunich Site, British Honduras. Actas y Memorias del XXXVI Congreso Internacional de Americanistas, España, 1964, Vol. 1, pp. 351-4. Seville.

Royal Ontario Museum Toronto, Canada

August, 1967 